\title{
Prevalence of Typhi DOT IGM positive results in COVID-19 patients at primary and secondary health care hospitals in Punjab, Pakistan.
}

1. MBBS, FCPS

Consultant Physician

Lifecare Hospital, Burewala,

Pakistan.

2. MBBS

House Officer

Allied Hospital, Faisalabad,

Pakistan.

3. MBBS

House Officer

Allied Hospital, Faisalabad, Pakistan.

4. MBBS

House Officer

Allied Hospital, Faisalabad, Pakistan.

5. MBBS, M.Phil

Assistant Professor Anatomy Azra Naheed Medical College, Lahore, Pakistan.

6. MBBS, M.Phil Scholar Biochemistry

University of Health Sciences, Lahore, Pakistan.

Correspondence Address:

Dr. Muhammad Saeed Aslam

House No. 37Z,

Hosing Scheme, Burewala

pearlinsoul@gmail.com

Article received on:

03/09/2020

Accepted for publication:

$19 / 11 / 2020$
Muhammad Saeed Aslam', Sidra Shabeer ${ }^{2}$, Rabia Majeed ${ }^{3}$, Fareeha Asghar ${ }^{4}$, Syeda Rizwana Jafri ${ }^{5}$, Humera Khan ${ }^{6}$

ABSTRACT... Objective: To determine prevalence of Typhi dot IgM positive results in COVID-19 patients at primary and secondary health care hospitals in Pakistan. Study Design: Descriptive Cross-sectional study. Setting: Tehsil Head Quarter Hospital of Burewala and District Head Quarter Hospital of Vehari. Period: $1^{\text {st }}$ March 2020 to $30^{\text {th }}$ June 2020. Material \& Methods: Study was done among diagnosed cases of COVID-19 after taking ethical approval from ethical review board. Results were assessed by using SPSS version-24. Results: Males were predominant $(71.30 \%)$ in our study as COVID-19 positives than the females. Most of the patients $(51.70 \%)$ were from middle aged group, i.e. 31-60 years. Only 7.40\% patients were from elder age group (more than 60 years). More than half of the patients $(51.90 \%)$ were found to be positive with IgM typhi dot test. We repeated the tests and found the same results. We also calculated the prevalence of typhoid positive cases in COVID patients according to different demographic variables. As far as gender is concerned, our result was highly statistically significant when associated with typhoid positive results among COVID patients $(P=0.0001)$. Males were predominantly having high rate of typhi dot IgM positives $(71.30 \%)$ than females. Middle aged patients were found to be more affected by typhi dot positive results. Conclusion: It is concluded that there is a high and significant ratio of typhi dot positive results for $\lg \mathrm{M}$ in COVID patients at Vihari district.

Key words: $\quad$ COVID-19, Patients, Typhi Dot IGM.

Article Citation: Aslam MS, Shabeer S, Majeed R, Asghar F, Jafri SR, Khan H. Prevalence of Typhi DOT IGM positive results in COVID-19 patients at primary and secondary health care hospitals in Punjab, Pakistan. Professional Med J 2021; 28(6):779-783. https://doi.org/10.29309/TPMJ/2021.28.06.6055

\section{INTRODUCTION}

Approaching end of December 2019, came with a catastrophic disease referred to as corona virus disease 2019 (abbreviated as COVID 19) emerging in Wuhan city of China ${ }^{1}$ turning into a global pandemic within couple of days as $\mathrm{WHO}$ declared it public health emergency on $30^{\text {th }}$ January 2020. ${ }^{2}$ The novel corona virus disease characterized by pneumonia like symptoms belongs to a family of SARS and MERS. ${ }^{2}$ The clinical symptoms include fever, dry cough, fatigue, myalgia, and dyspnea that lead to failure of the respiratory system and death. ${ }^{3}$ Being a developing country and geographical neighbour of China, Pakistan also facing a real time burden of the novel corona virus as no vaccine or sure short treatment regime is available till date. ${ }^{4}$ In Pakistan, the numbers of COVID-19 are continually on the rise and the condition is worsening, with around
225,283 infected individuals. $^{5}$

In recent era of advancement of COVID19, a parallel and simultaneous spike of typhoid fever cases has been noted within 10 days of June 2020 in Pakistan causing a burden to health care facilities. A total of 220 patients were tested for Salmonella Typhi in Lahore from March $15^{\text {th }}$ June $15^{\text {th }} 2020$. $^{6}$ Typhoid fever caused by fecooral transmission of a bacteria salmonella typhi, causing high grade fever, headache, rash, fatigue along with GIT symptoms. ${ }^{7}$ Besides, to the presentation of nonspecific symptoms of typhoid, they are similar to other diseases like malaria, dengue, and COVID-19. Due to the common symptoms of these diseases, it is difficult to identify the actual underlying cause without the proper diagnosis tests. ${ }^{7}$ Doctors are facing complications in the diagnosis and differentiating 
both diseases due to almost common symptoms like fever, fatigue, body pain, and diarrhea in some cases. ${ }^{8}$ A study was also conducted in west surgical unit Mayo hospital Lahore building a correlation of typhoid fever patients and COVID 19 patients in pre and post lockdown period.

The aim of this study is to establish any possible association between typhoid fever patients and covid19 patients in area of district Vehari.

\section{MATERIAL \& METHODS}

This cross-sectional survey was conducted at THQ hospital of Burewala and DHQ hospital of Vehari from $1^{\text {st }}$ March 2020 to $30^{\text {th }}$ June 2020 among diagnosed cases of COVID-19 after taking ethical approval $\left(27-14 / E R B / 27^{\text {th }}\right)$ from ethical review board.

Sample size was calculated by using following formula;

$$
\text { Sample size }=\frac{Z_{1-a z^{2}} p(1-p)}{d^{2}}
$$

$\mathrm{Z}_{1-\mathrm{a} / 2}=$ is standard normal variate (at $5 \%$ type 1 error $(P<0.05)$ it is 1.96. As in majority of studies $P$ values are considered significant below 0.05 hence 1.96 is used in formula.

$p=$ Expected proportion in population based on previous studies or pilot studies $=0.60(7)$

$\mathrm{d}=$ Absolute error or precision $=0.05$

Sample size $=369$.

Convenient sampling technique was used.

Only diagnosed cases of COVID-19 cases were included in surgery. Other patients with other diseases were excluded. An informed consent was taken before filling of questionnaire forms. Social distancing was made sure while conducting this study.

Data was assessed by using SPSS version-24. Demographic frequency distributions were calculated along with the percentage frequencies of different responses by the participants to the questions.

\section{RESULTS}

Male were predominant $(71.30 \%)$ in our study as COVID-19 positives than the females. Most of the patients $(51.70 \%)$ were from middle aged group, i.e. $31-60$ years. Only $7.40 \%$ patients were from elder age group (more than 60 years). More than half of the patients $(51.90 \%)$ were found to be positive with IgM typhi dot test. We repeated the tests and found the same results. We also calculated the prevalence of typhoid positive cases in COVID patients according to different demographic variables. As far as gender is concerned, our result was highly statistically significant when associated with typhoid positive results among COVID patients $(P=0.0001)$. Males were predominantly having high rate of typhi dot IgM positives (71.30\%) than females. Middle aged patients were found to be more affected by typhi dot positive results.

\begin{tabular}{|l|l|}
\hline Variable & \multicolumn{1}{|c|}{ Groups $\mathbf{n}(\%)$} \\
\hline Gender & $\begin{array}{l}\text { Male 316 (71.30) } \\
\text { Female 127 (28.70) }\end{array}$ \\
\hline Age & $\begin{array}{l}\text { Less than 30 181 (40.90) } \\
\text { 31-60 229 (51.70) } \\
\text { More than 60 33 (7.40) }\end{array}$ \\
\hline Symptoms & $\begin{array}{l}\text { Asymptomatic 334 (75.40) } \\
\text { Symptomatic 109 (24.60) }\end{array}$ \\
\hline Typhi Dot IgM Status & $\begin{array}{l}\text { Positive 230 (51.90) } \\
\text { Negative 213 (48.10) }\end{array}$ \\
\hline Typhi Dot IgG Status & $\begin{array}{l}\text { Positive 38 (8.60) } \\
\text { Negative 404 (91.40) }\end{array}$ \\
\hline Table-I. Demographic characteristics of study sample \\
$\mathbf{( n = 4 4 3 ) . ~}$
\end{tabular}

\begin{tabular}{|c|c|c|c|c|}
\hline Variables & & & & \\
\hline $\begin{array}{l}\text { Typhi } \\
\text { Dot IgM } \\
\text { Status }\end{array}$ & $\begin{array}{c}\text { Total } \\
(n=443)\end{array}$ & $\begin{array}{c}\text { Males } \\
(\mathrm{n}=316) \\
\mathrm{n}(\%)\end{array}$ & $\begin{array}{c}\text { Females } \\
(n=127) \\
n(\%)\end{array}$ & $\begin{array}{c}\text { P- } \\
\text { Value }\end{array}$ \\
\hline Positive & 230 & $\begin{array}{c}164 \\
(71.30)\end{array}$ & $\begin{array}{c}66 \\
(28.70)\end{array}$ & \\
\hline Negative & 213 & $\begin{array}{c}152 \\
(71.40)\end{array}$ & $\begin{array}{c}61 \\
(28.60)\end{array}$ & \\
\hline
\end{tabular}

Table-II. Prevalence of Typhi Dot IgM among COVID-19 patients in Pakistani population stratified by gender $(n=443)$. 


\begin{tabular}{|l|c|c|c|}
\hline \multicolumn{1}{|c|}{ Variables } & $\begin{array}{c}\text { Total } \\
(\mathbf{n = 4 4 3 )}\end{array}$ & $\begin{array}{c}\text { Asymptomatic } \\
(\mathbf{n = 3 3 4 )} \\
\mathbf{n}(\%)\end{array}$ & $\begin{array}{c}\text { Symptomatic } \\
(\mathbf{n = 1 0 9 )} \\
\mathbf{n}(\%)\end{array}$ \\
\hline Typhi Dot IgM Status & 230 & $179(77.80)$ & $51(22.20)$ \\
\hline Positive & 213 & $155(72.80)$ & $58(27.20)$ \\
\hline Negative & & P-Value & 1.542 \\
\hline
\end{tabular}

Table-III. Prevalence of Typhi Dot IgM among COVID-19 patients in Pakistani population stratified by Symptoms $(n=443)$.

\begin{tabular}{|l|c|c|c|c|c|}
\hline \multicolumn{1}{|c|}{ Variable } & $\begin{array}{c}\text { Total } \\
(\mathbf{n = 4 4 3 )}\end{array}$ & $\begin{array}{c}\text { Less than } \mathbf{3 0} \\
\mathbf{( n = 1 8 1 )} \\
\mathbf{n}(\mathbf{\%})\end{array}$ & $\begin{array}{c}\mathbf{3 1 - 6 0} \\
\mathbf{( n = 2 2 9 )} \\
\mathbf{n}(\%)\end{array}$ & $\begin{array}{c}>\text { 60 } \\
\mathbf{( n = 3 3 )} \\
\mathbf{n}(\%)\end{array}$ & P-Value \\
\hline Typhi Dot IgM Status & 230 & $92(40.00)$ & $118(51.30)$ & $20(8.70)$ & 1.098 \\
\hline Positive & 213 & $89(41.80)$ & $111(52.10)$ & $13(6.10)$ & \\
\hline Negative & $210)$ &
\end{tabular}

Table-IV. Prevalence of Typhi Dot IgM among COVID-19 patients in Pakistani population stratified by Age groups $(n=443)$.

\section{DISCUSSION}

The total number of COVID-19 positive patients presented to different hospitals of district Vehari was 443 . All presented with different symptoms and from different vicinities of district Vehari. There was no previous study which reported number of cases from this district of Punjab.

Males were predominant (71.30\%) in our study as COVID-19 positive than the females showing that females showed some kind of immunity against COVID at this district. A recent study showed the same results for gender inclusion. ${ }^{9}$ We also divided the COVID positive patients according to age into three groups. Most of the patients $(51.70 \%)$ were from middle aged group, i.e 31-60 years. Only $7.40 \%$ patients were from elder age group (more than 60 years). It was contrary to the results of recent study which shows that most of their patients were from elder age group. ${ }^{10}$ Patients were mostly stable when presented to hospitals $(75.40 \%)$. The cause of their presentation in the hospital was that they were exposed to the COVID positive contacts. It was also in oppose to a recent study which shows that patients were unstable mostly when presented. ${ }^{11}$

A recently published data showed that the number of typhoid positive results was quite less than that of our study in COVID positive patients. ${ }^{12}$ Almost $9 \%$ of COVID patients also presented with history of typhoid but they were not having active typhoid at the time of presentation.
We also calculated the prevalence of typhoid positive cases in COVID patients according to different demographic variables. As far as gender is concerned, our result was highly statistically significant when associated with typhoid positive results among COVID patients $(P=0.0001)$. Males were predominantly having high rate of typhi dot IgM positives $(71.30 \%)$ than females. Prevalence of typhi dot positives for IgM among COVID patients stratified by symptoms showed that most of them $(77.80 \%)$ were asymptomatic. Results were also non-significant $(P=1.542)$. A recent study showed that unstable patients were the most with typhidot positive for $\operatorname{lgM} .^{13,14}$ Similarly non-significant results were found when associated with age groups $(P=1.098)$. Middle aged were found to be more affected by typhi dot positive results.

A recent study suggests that the typhidot positive result for IgM in COVID patients before the diagnosis of COVID was made, led to wrong treatment as such patients were given antibiotics. ${ }^{15}$ So with the help of our study, every hospital dealing with COVID cases can make it a norm to have typhoid tests as well.

\section{CONCLUSION}

Hence it is concluded that there is a high and significant prevalence of typhi dot positive results for IgM in COVID patients at Vihari district. More studies are needed at bigger level in the Punjab 
province with larger sample size and special attention to be paid from higher authorities in this regard.

\section{Conflict of Interest}

The authors have no conflicts of interest to declare.

Copyright(C) 19 Nov, 2020.

\section{REFRENCES}

1. Pamplona J, Solano R, Soler $C$, Sàbat $M$. Epidemiological approximation of the enteric manifestation and possible fecal-oral transmission in COVID-19: A preliminary systematic review.

2. Wajahat M, Ahmed $H$, Sherwani SK. Knowledge, Attitude and Practice towards COVID-19 among General Public of Islamabad, Pakistan. International Journal of Basic Medical Sciences and Pharmacy (IJBMSP). 2020; 9(1).

3. Chaudhry RM, Hanif A, Chaudhary M, Minhas S. Coronavirus Disease 2019 (COVID-19): Forecast of an Emerging Urgency in Pakistan. Cureus. 2020; $12(5)$.

4. Waris A, Khan AU, Ali M, Ali A, Baset A. CoVID-19 outbreak: Current scenario of Pakistan. New Microbes and New Infections. 2020:100681.

5. Sarwar S, Waheed R, Sarwar S, Khan A. CoVID-19 challenges to Pakistan: Is GIS analysis useful to draw solutions? Science of The Total Environment. 2020:139089.

6. Haqqi A, Khurram M, Din MS, Aftab MN, Ali M, Ahmed $H$, Afzal MS. CoviD $\square 19$ and Salmonella Typhi co $\square$ epidemics in Pakistan: A real problem. Journal of medical virology. $2020 \mathrm{Jul} 10$.

7. Petrin CE, Steele RW, Margolis EA, Rabon JM, Martin H, Wright A. Drug-resistant Salmonella typhi in Pakistan. Clinical Pediatrics. 2020 Jan; 59(1):31-3.
8. Ochiai RL, Acosta CJ, Danovaro-Holliday M, Baiqing D, Bhattacharya SK, Agtini MD, et al. A study of typhoid fever in five Asian countries: Disease burden and implications for controls. Bulletin of the world health organization. 2008; 86:260-8.

9. Konwar AN, Borse V. Current status of point-of-care diagnostic devices in the Indian Healthcare System with an Update on COVID-19 Pandemic. Sensors International. 2020 Jun 9:100015.

10. Wu K, Saha R, Su D, Krishna VD, Liu J, Cheeran MC, Wang JP. Magnetic immunoassays: A review of virus and pathogen detection before and amidst the coronavirus disease-19 (COVID-19). arXiv preprint arXiv:2007.04809. $2020 \mathrm{Jul} 9$.

11. Requena-Méndez $A$, Berrocal $M$, Almela $M$, Soriano A, Gascón J, Muñoz J. Enteric fever in Barcelona: changing patterns of importation and antibiotic resistance. Travel Medicine and Infectious Disease. 2016 Nov 1; 14(6):577-82.

12. Trück J, Prader S, Natalucci G, Hagmann C, Brotschi B, Kelly J, Bassler D, Steindl K, Rauch A, Baumgartner $M$, Fingerhut $R$. Swiss newborn screening for severe $T$ and $B$ cell deficiency with a combined TREC/ KREC assay-management recommendations. Swiss Medical Weekly. 2020 Jun 24; 150(2526).

13. Mitsakakis K, D'Acremont V, Hin S, von Stetten F, Zengerle R. Diagnostic tools for tackling febrile illness and enhancing patient management. Microelectronic Engineering. 2018 Dec 5; 201:26-59.

14. Harris JB, Brooks WA. Typhoid and paratyphoid (enteric) fever. In Hunter's tropical medicine and emerging infectious diseases 2020 Jan 1 (pp. 608-616). Content Repository Only!.

15. Pandya KD, Palomo-Caturla I, Walker JA, Sandilya VK, Zhong Z, Alugupalli KR. An unmutated IgM response to the VI polysaccharide of Salmonella typhi contributes to protective immunity in a murine model of typhoid. The Journal of Immunology. 2018 Jun 15; 200(12):4078-84. 


\begin{tabular}{|c|l|l|}
\multicolumn{3}{|c|}{ AUTHORSHIP AND CONTRIBUTION DECLARATION } \\
\hline Sr. \# & Author(s) Full Name & \multicolumn{1}{c|}{ Contribution to the paper } \\
\hline 1 & M. Saeed Aslam & $\begin{array}{l}\text { Conception and design of work, } \\
\text { results compiling. } \\
\text { Help in biostatics and data analysis. }\end{array}$ \\
2 & Sidra Shabeer & $\begin{array}{l}\text { Supervision and revising it critically } \\
\text { for important intellectual content. } \\
\text { Final approval of the version to be } \\
\text { published. } \\
\text { Analysis and interpretation. }\end{array}$ \\
\hline 5 & Rabia Majeed & Fareeha Asghar \\
5 & Syeda Rizwana Jafri & \\
6 & Humera Khan & Write up of the article. \\
\hline
\end{tabular}

